Portland State University

PDXScholar

6-16-2021

\title{
Towards an Evolutionary-Institutional Analysis of Landlordship
}

Jaye Balentine

Portland State University

Follow this and additional works at: https://pdxscholar.library.pdx.edu/honorstheses

Part of the Political Economy Commons

Let us know how access to this document benefits you.

Recommended Citation

Balentine, Jaye, "Towards an Evolutionary-Institutional Analysis of Landlordship" (2021). University Honors Theses. Paper 1027.

https://doi.org/10.15760/honors.1055

This Thesis is brought to you for free and open access. It has been accepted for inclusion in University Honors Theses by an authorized administrator of PDXScholar. Please contact us if we can make this document more accessible: pdxscholar@pdx.edu. 
Portland State University

PDXScholar

6-16-2021

\section{Towards an Evolutionary-Institutional Analysis of Landlordship}

Jaye Balentine

Portland State University

Follow this and additional works at: https://pdxscholar.library.pdx.edu/honorstheses

Part of the Political Economy Commons

Let us know how access to this document benefits you.

Recommended Citation

Balentine, Jaye, "Towards an Evolutionary-Institutional Analysis of Landlordship" (2021). University Honors Theses. Paper 1027.

https://doi.org/10.15760/honors.1055

This Thesis is brought to you for free and open access. It has been accepted for inclusion in University Honors Theses by an authorized administrator of PDXScholar. Please contact us if we can make this document more accessible: pdxscholar@pdx.edu. 
Towards an Evolutionary-Institutional Analysis of Landlordship

\author{
by \\ Jaye Balentine
}

An undergraduate honors thesis submitted in partial fulfillment of the

\author{
requirements for the degree of \\ Bachelor of Arts \\ in \\ University Honors \\ and \\ Political Science
}

Thesis Adviser

John Hall, PhD.

Portland State University

2021 


\section{Introduction}

This inquiry seeks to advance an evolutionary-institutional analysis of 'landlordship.' Identified as an 'institution,' landlordship has held a prominent role in structuring property relations since the emergence of a nascent capitalism characteristic of the $15^{\text {th }}$ and $16^{\text {th }}$ centuries. As an identifiable class in society, landlords are still with us today, and continue to exist as key figures exerting effects over the lives of a considerable portion of the population living within the United States of America.

According to U.S. Census Bureau data analyzed by Pew Research Center (Cillufo et al., 2017), as of 2016, 43.3 million households rented in 2016 compared to only 34.6 million in 2006. This represents an increase from $31.2 \%$ to $36.6 \%$ of total households over a ten-year period, and by all indications this proportion has only grown since the data was collected. This same study shows that among these renters, younger people-and especially people of color-are disproportionately affected by the institution of landlordship. Given this already large and steadily increasing segment of the population that enters into contracts with landlords in order to secure housing, there exists a clear need for a renewed analysis of the function and role of landlords in the contemporary capitalist political economy.

This inquiry considers the extant literature on the emergence and development of landlordship under capitalism in order to construct a clearer picture of the evolutionary trajectory of this institution; considering where it has been and where it appears to be heading. Thus, there exists a secondary goal for this inquiry, and this involves demonstrating the usefulness of applying an evolutionary-institutional approach to the study of landlordship. 


\section{Methodology}

This inquiry makes use of evolutionary-institutional analysis by singling out landlordship as an institution that can also be situated against the backdrop of a capitalistic political economy. As such, this effort brings together and fuses two largely distinct methodologies: namely, evolutionary-institutional economics and Marxist political economy. While these two methodologies are often dealt with separately, in applying an evolutionary-institutional analysis to a particular capitalistic institution, it would be a mistake to separate the subject of analysis from its broader political economic context.

As a methodology, evolutionary-institutional economics can be traced back to its originator, economist Thorstein Veblen, and his key 1898 article: "Why is Economics Not an Evolutionary Science?" which appeared in the American Economic Review. In this article Veblen (1898) argues for a reassessment of economics as a discipline, noting that while other social sciences improved their analyses by introducing process-based logics, economics still adhered to notions of static data and unchanging conditions. Veblen $(1898,378)$ offers the term "cumulative causation" to embody this new approach. Lamentably, Veblen's efforts failed in displacing the dominant, Neoclassical school of thought. Nearly one half a century later, Gunnar Myrdal (1957) returned to the issue and offers an elaborated definition of the notion of cumulative causation. Myrdal $(1957,9)$ notes that among the inadequacies of the "inherited theoretical approach" is the myth of a "stable equilibrium."

What I can note herein is that there exists a tendency in the economics discipline (both in Veblen's day as well as presently) to believe that a given system or institution tends to self-correct, or respond to stimuli by reacting inversely; that is, through returning to an "ideal" or "normal" state. In contrast, notions of cumulative causation allow us to consider that - once initiated- 
changes tend to compound, setting trajectories for evolution which, rather than self-correct, can actually accelerate. With success, Myrdal applied this understanding towards the analyses of economic systems, shedding needed light on differences between developments taking place between "rich" and "poor" countries and how paths of development form. With this inquiry I shall demonstrate that Myrdal's concept of cumulative causation is just as applicable to the analysis of any single institution, given that all institutions exist in a constant state of change—of evolution.

Analyses of landlordship that treat contemporary landlords as a rigid or stable institutional form fail to consider that behind what we can observe in the present we need to also consider a larger historical trajectory, and the reality that even now, the institution of landlordship continues to undergo processes of evolutionary change. In Myrdal's $(1957,18)$ words:

...the main scientific task is... to analyze the causal interrelations within the system [or institution] itself as it moves under the influence of outside pushes and pulls and the momentum of its own internal processes."

Such an analysis allows the identification and study of what Myrdal $(1957,7)$ terms a Teufelskreis — a "vicious circle"—or, inversely, a "virtuous circle." These terms represent the either socially beneficial or socially deleterious evolutionary trajectories which a given system or institution may embark upon, stimulated by internal processes, outside influences, and, often, a synergic combination of the two.

Additionally, Myrdal (1957, 10) argues that any analysis which focuses narrowly on "economic factors" would lead to conclusions divorced from reality. An effort which privileges economic factors would fail to account for the various historical, political, and social factors engaged in an evolutionary interplay. While the landlord should primarily be seen and understood for their economic position, an analysis of landlordship as an institution must consider this wider variety of factors and their intersections. As such, political economy becomes a far more effective 
approach than any methodology offered by the dominant Neoclassical school of thought stemming from Alfred Marshall and Leon Walras. Marxist political economy, in particular, could offer a robust analysis of the mechanisms of the capitalist system while also accounting for historical, social, and political variables. Central to the analysis at hand is the acknowledgement that landlords must be recognized as members of the capitalist class. While the consolidation of the landlord into this class shall be elaborated on below, it is here worth noting that inherent to this landlord class and its position among the bourgeoisie is the functional reality of landlords as extractors of value from the working class. Even feudal landlords exercised this role, though it took on a new character under capitalism, and this transformation is central to an analysis of contemporary landlordship.

Evolutionary-institutional inquiries must also acknowledge and explore the particular mechanisms by which changes are initiated in a given institution. The most significant mechanism for the inquiry at hand is that of "subreption." This is a term drawn from philosopher Immanuel Kant, whose understanding of subreption is introduced in his Inaugural Dissertation from 1770. Bearing the title: On the Form and Principles of the Sensible and Intelligible Worlds, this dissertation secured Kant an academic post at the university in Königsburg, located in East Prussia (see Handyside, 1929). In this dissertation, Kant seeks to define the term vitium subreptionis metaphysicum. In English, this phrase translates to the fallacy of subreption, or, simply, subreption. This Kantian notion of subreption suggests the introduction of a falsehood, or a "metaphysical mistake," which serves to corrupt further reasoning. As described by John Hall et al. $(2016,479)$ in the article "Subreption, Radical Institutionalism, and Economic Evolution," Veblen studied Kant during the pursuit of his own Ph.D. in Philosophy, and later integrated Kant's notion of subreption into social science inquiry. With this in mind, we can summarize that the Veblenian 
notion of subreption goes beyond distorting human reasoning and represents how the introduction of an out of place practice or principle — a 'falsehood'-into a given institution can over time distort the values of that institution and result in observable changes. William Dugger $(1980,901)$ points to Veblen's 1918 Higher Learning in America as “perhaps the best study of subreption ever written." In this text Veblen interrogates the changes which occurred in the institutions of higher learning in medieval Europe as well as the United States at the turn of the $20^{\text {th }}$ century. Veblen saw that the institutions of higher learning were subrepted by the introduction of business values, which shifted the goals of higher education away from the dissemination of knowledge and towards the pursuit of money and the production of individuals similarly oriented towards the pursuit of money (Dugger, 1980, 901). For the present inquiry, understanding how the political, social, and economic aspects of landlordship have changed requires an understanding of the underlying logics and values which govern and direct the actions of those occupying this social position and bringing life to the institution. Thus, attention will be directed to the introduction of what Veblen [1904] $(2005,37)$ termed "pecuniary" — that is, money-oriented-logics and values to landlordship, and how this becomes the vehicle by which capitalist means and ends come to characterize the institution.

Another crucial variable to an understanding of landlordship is the phenomena which Karl Marx termed "alienation." While often confined to its definition in relation to the labor process, scholars such as David Harvey $(2018,137)$ emphasize that Marx also recognized that alienation can indeed extend beyond the labor process and thereby affect many aspects of life under capitalism. For the project at hand, understanding how and when the alienation between landlord and tenant, landlord and land, and land and tenant emerged is crucial. In exploring the emergence of this alienation, this effort seeks to demonstrate that the subreption of the institution of 
landlordship by pecuniary logics sets off an evolutionary trajectory which closely resembles Myrdal's notion of a vicious circle. In the case of landlordship, the introduction of alienating logics began a cumulative process of an ever-increasing degree of alienation which has continued until today. This inquiry analyzes this historical development, its consequences, and the possibilities for breaking out of this vicious downward spiral.

\section{The Emergence of Capitalist Landlords}

The first relevant subject in constructing an evolutionary trajectory of landlordship under capitalism leads us to the emergence of capitalist landlords. Historian Robert Breyer (2004) offers an analysis of the emergence of capitalist landlords in England in the $18^{\text {th }}$ century. In any evolutionary-institutional analysis, it is necessary to identify which variables drive evolution and understand how they instigate change in an institution. Breyer's $(2004,3)$ analysis provides a look into this process by focusing on the accounting habits of English landlords, arguing that it was the adoption of capitalist mentalities - namely the 'rate-of-return-on-capital mentality' - and the subsequent spreading of capitalist social relations which drove this process. Breyer $(2004,5)$ explains that under the feudal mentality, landlords sought to directly extract surplus labor from self-sufficient, landed peasants inhabiting the landlord's estate by appropriating labor, commodities, or cash. Thus, the accounting habits of feudal landlords reflected a basic tracking of income and expenditure. In contrast, Breyer continues, once the capitalist mentality is adopted, landlords shift to seeking a rate of return on the capital employed in production by appropriating the surplus value generated through wage labor.

Breyer $(2004,6)$ finds that the first instances of wage labor in English agriculture occurred

independently of any landlords' intentions. Rather, some English farmers in the mid-16 ${ }^{\text {th }}$ century 
managed to enclose - that is, close off land from common use and restrict it to private accesssmall areas of fertile land and switched over to a wage labor system (this occurred roughly two centuries before the more formalized and well-known enclosure movement of the $18^{\text {th }}$ century driven by Parliament). However, these farmers did not fully adopt a capitalist mentality-they sought increased agricultural output, not a rate of return on capital per se. The first instance of the rate-of-return-on-capital mentality, Breyer $(2004,6)$ argues, can be found around the same period in the newly emerging joint-stock companies. While these collections of (typically urban) merchants represent the more commonly recognized pioneers of the capitalist mentality, it was the flow of capital between rural tenant farmers and these merchants which allowed this development to occur. Breyer $(2004,6)$ explains that capital first flowed from the land to the merchants and the resulting flow of capital back into the hands of farmers brought with it the rate-of-return-oncapital-mentality. The combination of simple wage labor used by the farmers with this new disposition combined to form the first true capitalist mindset.

These farmers were distinct from both the self-sufficient peasantry as well as the landlord. Rather, the landlord extracted rents either directly from the peasants or from tenant farmers who, as a result of successful enclosures, managed to insert themselves as a middleman between those conducting labor and the landlord. Thus, as explained by Breyer $(2004,7)$, the landlord was not intentionally capitalistic. It was tenant farmers who played a key role in converting a small number of the peasant population into 'free' laborers, thus converting landlords into "de-facto capitalists." As the flow of capital began to increase, landlords took on a more active role in seeking to lease their land to tenant farmers in exchange for cash rents, rather than direct surplus from landed peasants. While initiated by individual tenant farmers, this process gained momentum in the $18^{\text {th }}$ century with the Parliament-backed enclosure movement, which effectively completed the process 
of divorcing peasants from the land on which they both lived and worked, creating the population of free laborers central to England's industrial revolution. In addition, this period of change saw the shift away from feudal rents - the direct appropriation of commodities, labor, or cash from peasants producing for themselves - and towards capitalistic rents. As landlords began leasing more of their land to capitalist farmers, the landlords themselves adopted the rate-of-return-oncapital-mentality. Land was no longer simply a surplus-producing estate, but a form of capital which could fetch differing rates of return depending on its use. Seeing the clear increase in potential rent from leasing to capitalist farmers, Breyer $(2004,8)$ explains, landlords capitalized on this opportunity by "clearing the land of excess mouths" and seeking to maintain the highest possible level of labor productivity. It is in this form that we find the capitalist landlord fully realized.

This process of change, the replacing of one set of logics with another, represents a clear instance of subreption. To restate the Veblenian definition, this term refers to value changes which result in observable shifts in a given institution (in Hall et al., 2016, 470). Economist William Dugger $(1980,901)$ notes subreption as one of the primary "social mechanisms" which drive institutional evolution, explaining that society tends towards a state of "institutional hegemony," whereby the means and ends of one institution become the means and ends of all adjacent institutions. During the emergence of capitalism in England, the for-profit business-i.e. the capitalistic enterprise-represents such an institution. Therefore, the new logic of accumulation, that is, the rate-of-return-on-capital-mentality, subrepted the logics and values which previously governed and shaped the institution of landlordship, transforming it into a capitalistic institution and landlords themselves into members of the capitalist class. 
Another important aspect to this transition, and an instigating factor in this process of subreption, was the emergence of land markets in Britain in the $17^{\text {th }}$ century. In Capital Vol. 3 , Marx [1894] (1959a, 582) explains that these markets opened up investment in land to "urban and other moneyed people," allowing those already fully embracing the rate-of-return-on-capitalmentality to become landlords. Such individuals viewed these investments and the resulting rents as nothing more than another interest-yielding investment. Marx (1959a, 582) notes that the shift from feudal to capitalistic rent and the accompanying "alienability and alienation" was a "crucial factor" to this opening of land to private ownership and investment. It was the abandonment of non-economic bonds and the embrace of strictly capital-oriented (pecuniary) relationships to land which allowed for land markets and capitalist landlords to emerge, which in turn enabled increasing degrees of alienation as these social forms became the dominant social forms. Thus, the subreption of the institution of landlordship by capitalist logics successfully suppressed those aspects of the feudal arrangement which fostered non-economic bonds between tenants, landlords, and land.

While the more apparent changes which this process entailed - the new focus on capitalist rent, the displacement and proletarianization of the peasantry, the increased privatization of land, etc. - all had significant impacts, there is one phenomenon underlying all of these: the emergence of alienation due to the new capitalistic social relations. Feudalism was a deeply exploitative and violent social order, however there existed certain bonds between landlords, tenants (the peasantry), and the land which were eroded with the emergence of capitalist landlords. Figure 1 outlines a simplified representation of these relationships under English feudalism just before the evolutionary process detailed above began in earnest. The landlord-tenant-land relationship under this feudal system was highly exploitative of the peasantry, however the connections between 


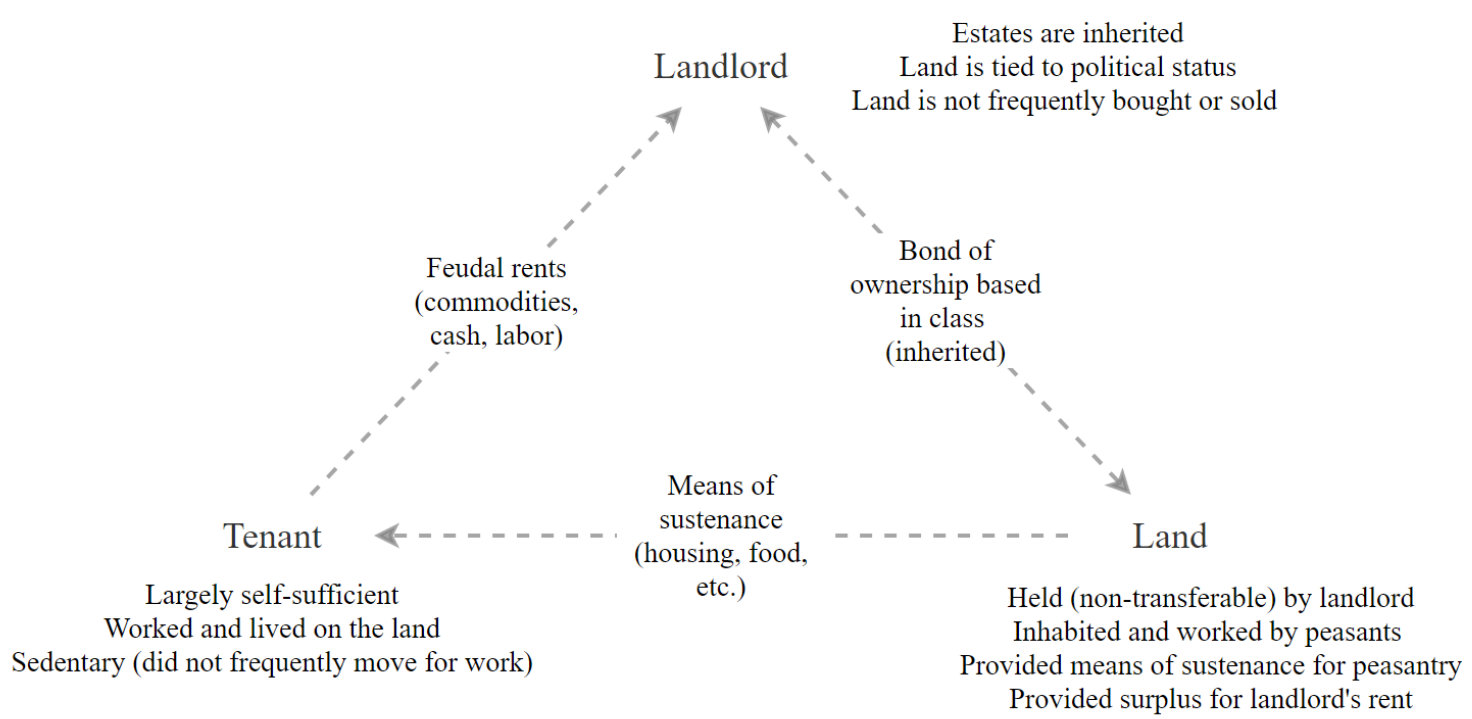

Figure 1. Simplified model of feudal landlordship

those involved were complex and multifaceted. Peasants not only worked the land but lived on it and drew their means of sustenance from it. While landlords extracted feudal rents from the labor of the peasantry, the estates on which this work occurred were tied to the landlord through bonds of inheritance and political status. As such, both the landlord and the tenants held a vested interest in maintaining the quality of the land, and the landlord holds an interest in at least a minimal degree of security for the peasantry (safe from direct violence and also stable enough to continue working). Marx [1844] (1959b, 36-37) notes that this connection between peasant and landlord is "directly political" and possesses "a human, intimate side." These bonds, formed both by necessity (the maintenance of feudal rent) as well as tradition and politics (the bonding of tenants to land and therefore to the landlord), find themselves dramatically disrupted with the introduction of the rate-of-return-on-capital mentality and its implications. 
What emerges and comes to characterize these relationships is the presence of alienation, or estrangement. The alienation of peasant from land stems from displacement and proletarianization. Peasants are transformed into 'free-laborers,' unbonded to any piece of land and therefore 'free' - and compelled - to become mobile in search of wage-labor. Similarly, these changes sever the connection between housing and labor. As such, a distinction emerges between landlords who extract rent from productive enterprises (agriculture, industry, etc.) and those who extract rent from housing. Each sort of rent, at this point in the evolution of landlordship, is capitalistic rent, collected as cash rents and sought after as the highest possible rate of return on the capital advanced. While plenty of landlords may fall into both categories - by owning land occupied by both productive enterprises and housing — for analytical reasons this overlap will be ignored and moving forward only those landlords who extract rent on housing will be considered. This more general overview of the origins of capitalist landlords was necessary to identify the initiation of this particular evolutionary trajectory, that is, the subreption of the institution of landlordship by alienating capitalistic logics. Figure 2 offers another simplified sketch of the relationships at hand given the transformations caused by the emergence of capitalist landlords. This new model of landlordship casts away those human bonds which softened the exploitative and still violent feudal social relations. In place of these social bonds the act of exchange steps in. The relationship between landlord and land is now one of shifting capital into the place and form in which it will fetch the highest rate of return. Tenants no longer live and work in one place to which they can form long lasting bonds, but rather are compelled to hand over a significant portion of their wages to whichever landlord offers a lease that they can afford. Should they experience a decrease in income, they will be forced to abandon that contract to move somewhere where rent is lower. The only connection between tenant and land is that of affordability and exchange. The 


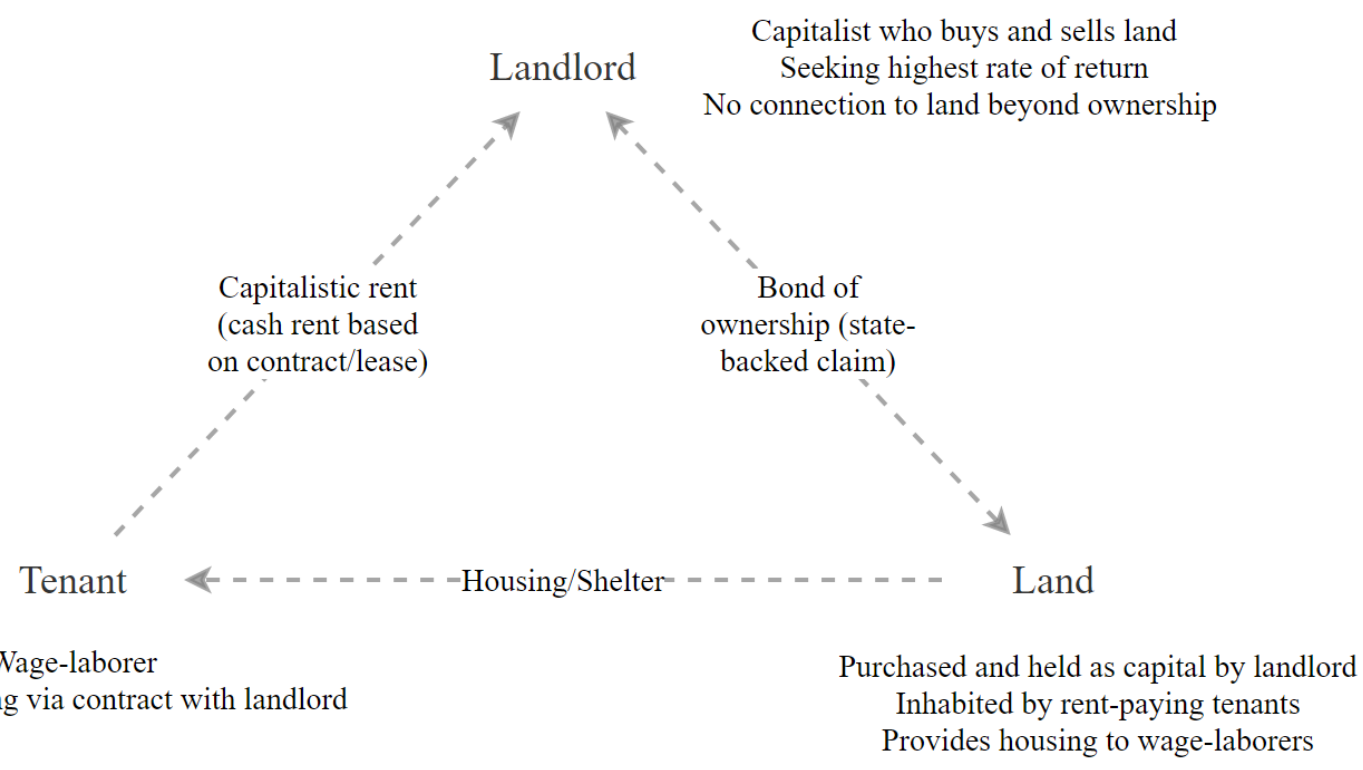

Figure 2. Simplified model of capitalistic landlordship

landlord now exists solely as the mediating figure between wage-laborers and the society's housing stock, and therefore as the alienating figure who maintains a barrier of exchange between person and shelter. As a result, neither party has a vested interest in the wellbeing of the land itself outside of their bonds of exchange. While the tenant certainly hopes to live somewhere clean and environmentally secure, they have little power over those conditions. That power lies in the hands of the landlord whose interest lies solely in the rate of return. If it proves profitable, the landlord will certainly maintain both the physical housing and the land upon which it is built, though as soon as this proves less-than-profitable, such concerns are readily abandoned.

This, in large part, is due to the mechanisms of capitalistic rent as opposed to feudal rent. While feudal rent consisted of direct payments of labor, cash, or commodities drawn from whatever surplus the working of the landlord's estate produced, capitalistic rent seeks the highest rate of return. David Ricardo [1817] (2001) offers a foundational theory of ground rent which 
discusses the variation between differing rents. Ricardo $(2001,41)$ explains how as long as multiple portions of land are appropriated, any differences in "productive powers" will result in differential rents. That is, if two areas of farmable land are brought under cultivation, and one has more fertile soil than the other, then the potential rent on this land will be greater than that of the less fertile land. Under the newly emerging capitalist system, land becomes a form of capital, and thus this differential rent represents differing rates of return on capital. However, Ricardo (2001, 42) stresses that there is a difference between the value derived from the land itself and the value derived from capital expended upon the land. That is, as Ricardo $(2001,42)$ explains, should the same amount of additional capital be expended upon two plots of land of differing quality, the difference between the two yields represents the rent. Under feudalism, this differential could result in squabbles over plots of land, but estates were less fluid before the commodification of land. Under capitalism, it becomes significantly easier to sell less profitable (lower-rent-yielding) land and pursue land of higher quality due to land markets. Additionally, land may yield different rents depending on type of use; for example, land which provides little rent for agriculture may prove very profitable for housing or industrial use. Should a landlord base their decisions purely in the rate-of-return-on-capital-mentality, then not only will land be bought and sold to achieve the most advantageous position in terms of potential rent, but also the use of land will be shifted into its most profitable use, regardless of the non-economic costs of such a transition. This phenomenon ties closely to what Breyer $(2004,8)$ termed "the clearing of excess mouths." Because the power and agency over the purpose and use of the land rests with the landlord, the tenants find themselves vulnerable to displacement should their presence on a given plot of land have a negative effect on the potential rate of return for the landlord. 
While the introduction of alienating logics into the institution of landlordship should certainly be of interest to any of those concerned with property relations and the ability of the working classes to house themselves, this process has been well documented and explored by existing literature. The purpose of this review was to provide a foundation upon which the cumulative and ongoing process of increasing alienation, due to the introduction of pecuniary values, may be demonstrated. Additionally, it should now be clear that changes within and around the institution of landlordship, namely the subreption of existing logics by the rate-of-return-oncapital-mentality, were the result of an evolutionary process and set the course for future changes in the institution. The following section will explore how the alienation of tenants from their landlords and the solidification of landlords into the capitalist class enabled further alienation by improving and reshaping landlords' ability to extract surplus value from the working classes.

\section{The Development of Capitalist Landlords in a Racialized Political Economy}

The subreption of the institution of landlordship by capitalist values and logics — and the resulting transformation from a feudal to a capitalist institution-brought with it the immediate effects described above. Additionally, this transition led to the formation of a new role for landlords in the now dominant capitalist system. Central to this role was the new class position of landlords, becoming members of the bourgeoisie rather than a distinct class. Most of the classical economists — such as Adam Smith and David Ricardo — considered society to be divided into three predominant classes: landlords, workers, and owners. To them, there remained a difference between landed capital controlled by landlords and the capital controlled by industrialists and other members of the 'owner' class. Marx [1848] (2010, 35), in contrast, argued that given the transition of land into a form of capital and the adoption of capitalist logics by landlords, these individuals 
were incorporated into the emergent bourgeoise, noting that "no sooner is the exploitation of the laborer by the manufacturer... at an end, that he receives his wages in cash, than he is set upon by the other portions of the bourgeoisie: the landlord, the shopkeeper, the pawnbroker, etc." (emphasis added). In other words, as soon as the laborer receives their wages (already having lost some of the value of their labor to the employer), their wages are further reduced by other members of the bourgeoisie, including the landlord. This understanding of landlordship places the extraction of rent from workers for the purpose of housing alongside the extraction of surplus value which occurs in the workplace, acknowledging the parallel functions of these two segments of the bourgeoisie. The following section will explore capitalist rent on housing as a form of value exploitation and how this serves to further the alienation described above, particularly in the context of an already racialized political economy.

In Capital Vol. I, Marx [1867] $(2011,255)$ demonstrates how surplus value is extracted from workers under a system of wage-labor. While other economic theorists of the $18^{\text {th }}$ and $19^{\text {th }}$ centuries treated rent and profit as "deductions" from wages (the value produced by labor), Marx $(1959 b, 11)$ instead demonstrates that wages are a "concession" which owners of capital allow from the product of labor. By acknowledging the complicity of landlords in the activities of the bourgeoisie, it becomes clear that the extraction of rent is part of the total accounting of the production of value. As Donald J. Harris $(1978,139)$ explains it, the "total pool of surplus value" is divided between the "various capitalist claimants," including landlords via rent payments. Labor creates the value, the capitalists of the workplace take the lion's share and 'concede' wages to the worker, and then the capitalist landlord takes their cut after the fact, further decreasing the total quantity of conceded wages which go to the worker. The burden of delivering the landlord's share falls on the worker and occurs outside of the site of value production (the workplace), which aids 
in obscuring the role of the landlord as central to the general production of value. Without housing, the working class could not continue to labor at the same level of productivity and consistency. Thus, the landlord has positioned themselves in an "indispensable" role, for if they cease to lease housing to the working class, capitalist production cannot continue apace. Their share of extracted surplus value simply arrives outside of the workplace, making it less apparent.

With this understanding of landlords as extractors of surplus value in mind, one can reconceptualize Ricardo's theory of differential rent discussed previously. Marx (2001, 331) explains how the extraction of value from the working class in the workplace can be measured as a "rate of surplus value" - or a rate of exploitation — that is, the proportion of value created by the worker which is then appropriated by the capitalist. When it comes to housing rent in particular, the amount of rent extracted similarly comes to represent a rate of exploitation which, in accordance with Ricardo's theory of ground rent, is variable. This variation mirrors variations in the rate of exploitation which occur in the workplace, with the most marginalized segments of society experiencing what Harris $(1972,11)$ accurately identifies as "super-exploitation." This relatively greater rate of exploitation (relative, that is, to other exploited members of the working class under otherwise similar conditions) is enabled through a number of structural factors including government policy, corporate hiring practices, financial lending practices, etc.

Crucially, one must recognize that the notion of super-exploitation comes from Marxist theorizations on the relations between metropole (the homeland of the colonizing power) and colony. While originating in Marx, V. I. Lenin [1917] $(1999,106)$ further articulated how through colonial relations, capitalist nations were able to extract "superprofits" from their colonies by maintaining a disproportionately high rate of value exploitation. This is the interpretation which Harris $(1972,10-11)$ carries forward, arguing that the presence of super-exploitation indicates the 
colonial nature of Black neighborhoods in the U.S. By identifying Black neighborhoodsparticularly the Black ghetto_ as "internal colonies," scholars such as Ron Bailey (1973) implicate colonial strategies of value extraction in the internal dynamics of landlordship within the U.S. While the theories and mechanisms of colonial domination typically consider only those colonial projects which exist outside of the metropole, Robert Blauner $(1969,395)$ explains, it is important to recognize how colonial dynamics can exist despite the lack of a "geographically external political unit." The importance of internal colonialism to the inquiry at hand is the recognition that landlords, as a consequence of their consolidation into the bourgeois class, begin to carry out the roles of said class. Given that a process of internal colonial exploitation is being carried out in the U.S., landlords become implicated in this process, and therefore begin to employ mechanisms of colonial extraction.

One particular mechanism which illustrates the colonial relationship and enables the superexploitation of racialized minorities in the sphere of rent and housing is the presence of "absentee landlords." This refers to those landlords who own rental properties yet do not live in the neighborhood or local area. During the $19^{\text {th }}$ and $20^{\text {th }}$ centuries this was especially true of rental opportunities available to Black communities in the United States. N. D. B. Connolly $(2009,250)$ uses Miami as a case study and finds that in the mid- $20^{\text {th }}$ century, "white absentee landlords owned a full 70 percent of the Black-occupied rental housing." While the general forms of housing alienation discussed earlier still hold, we find that in a racialized political economy exploitation across racial lines allows for an additional level of alienation whereby racialized communities must secure housing from those outside their community. This leads to extraction on a larger geographic scale as well, given that not only is value being extracted from individual workers and their households, but whole communities experience an extraction of value out of their neighborhoods, 
preventing any opportunity for localized reinvestment which could have otherwise at least somewhat improved the quality of life of the working class in the area.

Another aspect of this particular form of super-exploitation is the well-documented tendency for extreme undermaintenance of rental properties. Neil Smith $(1979,544)$ notes that undermaintenance of rental properties may not be a constant across real estate investments but is an entirely 'reasonable' course of action for landlords operating under capitalist values and logics. The twin pressures of both a) achieving the highest possible rate of return, and b) surviving in a competitive marketplace, drive landlords to maintain profit margins above all else, even the habitability of their rental properties. For instance, as explained by Ira Lowery $(1960,367)$, "undermaintenance is an eminently reasonable response of a landlord to a declining market." Thus, the quality of the "product" which tenants are being sold can decrease, while rents remain at the same rate, or even increase, thus increasing the rate of exploitation. This instance illustrates very clearly the consequences of the subreption of landlordship by capitalist values. Any preexisting values which encouraged fostering human relationships or prioritizing a degree of stability or comfort for tenants are replaced by the exclusive concern for pecuniary values. It is worth reemphasizing that feudalism was hardly a humane or comfortable system for tenants, the point here is that non-economic values existed under the value system of feudal landlords. The evolutionary trajectory of the institution could have carried these values forward and improved the conditions of tenants and workers - thus forming a virtuous circle — but instead, due to the process of subreption by capitalist values, has stripped away any human-centric values in favor of pecuniary interests - forming the vicious circle apparent today.

Continuing forward into the $21^{\text {st }}$ century, yet another consequence of capitalist landlords in a racialized political economy has emerged. Commonly referred to and understood as 
'gentrification,' this term describes the process by which existing (typically urban) areas are redeveloped to increase their economic value. Smith $(1979,545)$ offers a compelling definition of gentrification as "capital revaluation," and to help explain this phenomenon offers the concept of the 'rent gap.' This term refers to the gap between the "potential" ground rent and the "actual" or capitalized ground rent which a landlord collects. The idea of the rent gap is consistent with the Ricardian conception of variable ground rent. When the capitalized ground rent of a given property falls - due to shifting markets, building depreciation, changes in urban development, etc.—or when the potential ground rent rises — due, for instance, to rising property values in inner citiesthen a rent gap emerges. Given that capitalist landlords ground their decision making in pecuniary values, the 'rational' path forward would be to attempt a closure of the rent gap, bringing the actual ground rent as close to the potential ground rent as possible. This requires the revaluation of the relevant capital—the land and buildings owned—or, in other words, redevelopment.

Redevelopment (and therefore gentrification) is most profitable in areas where the rent gap is the widest. Given the particular geographies and histories of U.S. urban centers, the rent gap is highest in historically Black inner-city neighborhoods. Smith $(1979,546)$ notes that in the midto-late $20^{\text {th }}$ century, capital flowed out of cities and into suburbs following white families fleeing urban areas. While inner-city neighborhoods, during this period, proved highly profitable for absentee landlords due to the possibilities for a high rate of exploitation, capital itself remained sequestered in the suburbs. Given the depreciation of inner-city neighborhoods-due in no small part to the previously mentioned processes of undermaintenance - and the renewed interest in urban living among better-off (whiter) segments of the population, the late $20^{\text {th }}$ and early $21^{\text {st }}$ century has seen a widening of the rent gap in such urban areas, and therefore lucrative opportunities for redevelopment. Here, once again, we see the consequences of an alienated 
population of tenants living in tension with capitalist landlords. Tenants lack any state-recognized claims to the land which they inhabit, because their alienated position leaves them as little more than customers who can be denied service at the whim of the seller (the landlord). The capitalist landlord is not only compelled by the rate-of-return-on-capital-mentality to participate in capital revaluation and the raising of capitalized ground rent, but is similarly compelled by their own survival as landlords, given that a refusal to participate in the competitive market will see them priced out or bought out by those willing to engage in redevelopment. Thus, as long as landlords continue to operate under capitalist logics and values, gentrification becomes an inevitability.

The displacement which characterizes gentrification efforts mirrors that displacement which accompanied the emergence of capitalist landlords, as well as reinforces the salience of the colonial framework. Breyer's $(2004,8)$ description of "clearing the land of excess mouths" again finds relevance, as communities which lived in a given neighborhood, sometimes for multiple generations, are once again swept away in order to convert the land into its most profitable form. As has been discussed, it is disproportionately those communities subjected to internal colonialism who experience this displacement. The apparent repetition of such processes reflects the cumulative logic of Myrdal's vicious circle. Socially harmful occurrences like the displacement of entire neighborhoods and communities continue to occur and become increasingly incorporated into the institutional structures of society. Landlords at this point are fully realized capitalists with little resemblance to any pre-capitalist formation, who act in accordance with the functions of the capitalist class: extraction of surplus value and super-exploitation of surplus value among colonized populations. There is no 'flaw' in the system which allows for socially harmful events like displacement to occur; such events are now built into and facilitated by the institutional structures of the society, allowing for, and even encouraging, their continuation. In short, the 
introduction of capitalist logics into landlordship not only created capitalist landlords but created the conditions for the continued and cumulative expansion of capitalist landlordship and the concurrent alienation of working-class tenants.

\section{The Emergence of Corporate Landlords}

In considering the evolution of landlordship as it has continued to the present day, we encounter yet another notable stage in this evolutionary trajectory: the emergence of corporate landlordship. Also referred to as the 'financialization' of landlordship or the emergence of 'institutional investors,' this process can be generally defined as the shift away from an individual who operates as a capitalist landlord, to some form of conglomeration such as a rental company or an investment firm. Desiree Fields and Sabina Uffer $(2016,1486)$ explain how this phenomenon emerged in the 1980's as "the rise of financial services, an expanded real estate industry, and state redevelopment of city centers" made real estate in urban areas more accessible to global capital flows. The result is what Fields and Uffer $(2016,1486)$, among other scholars, have identified as 'land as a financial asset.' While the earlier part of this paper explored the shift of land from an inflexible, fixed allotment under feudalism to an exchangeable and return-yielding asset under capitalism, this most recent stage in the evolution of landlordship sees land converted into an abstracted financial asset, further divorcing it from its material reality as the site of shelter for human beings. Additionally, the landlord themself is now abstracted from an individual and replaced by an institution such as a rental company or a private equity firm. This represents a new phase in the evolutionary trajectory which has been sketched out thus far, and similarly represents the highest level of alienation seen. The following section will explore the emergence and expansion of the corporate model of landlordship, as well as its implications. 
The financialization of housing emerged as the result of a number of converging factors. However, as Fields and Uffer $(2016,1488)$ explain, this development is unmistakably tied to the neoliberal turn. With this shift in government policy away from state services and towards increased liberalization of the economy, states abandoned efforts at expanding-or even maintaining — public housing and increasingly shifted the responsibility for affordable housing onto the free market. Fields and Uffer $(2016,1488)$ note that this transition saw governments choose "to transfer public loans to private loans; demolish or privatize public or social housing; reduce supply-side subsidies in favor of housing allowances; promote home ownership; and deregulate rent." This sets the stage for an increased privatization of affordable housing, and the globalization of capital markets allowed for global capital to seize the moment and flow into rental real estate. Fields and Uffer $(2016,1489)$ describe how the combination of high risk with the potential for high returns made private equity funds an effective vehicle for packaging and selling off rental properties, be they former public housing projects or rental stock previously owned by smaller capitalists cashing out on their investments. Funds invest and take control of housing stock in two ways: the direct purchasing of real estate for the purpose of extracting housing rent, or more indirectly through the shareholding of rental companies (Fields and Uffer, 2016, 1489). In each form, the landlord takes the shape of a distant corporation. This corporate landlord only interfaces with the tenants through employees of whatever rental company actually facilitates the leasing of units and collecting of rents. Thus, while the petty-capitalist landlord like those described previously increasingly fade from existence, the new generation of landlords vanish from the immediate location of exchange and are obscured behind the dense façade of corporate bureaucracy. Similarly, by divorcing the institution of landlordship from a single individual, the rate-of-return-on-capital-mentality ceases to be a mindset of a human being-and therefore 
vulnerable to mediation by other human drives and motivations - but instead becomes the sole guiding principle of a non-human entity functioning strictly for the purpose of maximizing return on investment.

Once again, the scholarship of evolutionary-institutionalists becomes highly relevant to understanding these evolutionary processes. Returning to Dugger's $(1980,898)$ discussion on institutional hegemony, it becomes clear that with the shift from smaller, petty-capitalist landlords to larger, corporate landlords, a new hegemon in institutional structure has emerged. The above discussion of the emergence of capitalist landlords during the period of nascent capitalism noted that landlordship followed in the general trend towards emulating the newly dominant institution: the for-profit enterprise based on the rate-of-return-on-capital-mentality. With the contemporary shift towards corporatization, Dugger $(1980,901)$ offers the notion of "corporate hegemony," that is, the emergence of the corporation as the hegemonic institution which all other institutions come to emulate. Dugger's (1980, 901-903) discussion generally concerns the penetration of nonpecuniary institutions by the money-oriented logics and structures of the corporation, however it is equally important to acknowledge the transformation of already-economic institutions into specifically corporate formations. While the 'internal processes' of landlordship - to return to Myrdal's $(1957,7)$ conceptualization of evolutionary change-are already governed by the pecuniary values which subrepted the institution back during the transition out of feudalism, we now witness an outside pressure to corporatize. In the specific case of landlordship, this is primarily driven by the financialization of housing. This shift builds upon the previous waves of evolutionary change whereby the institution of landlordship was increasingly reoriented towards a purely profit-driven orientation, leading up to the contemporary transformation of landlords into non-human, corporate entities. 
This process, while emerging with the neoliberal turn in the 1970s and 80s, gained new momentum with the financial crash and emergent housing crisis in 2008. Elora Raymond et al. $(2016,2)$ explain how following the mortgage crisis, banks found themselves with a glut of properties which needed to be sold quickly, and due to a lack of credit among potential home owners, banks sold off these properties to hedge funds and private equity firms. The researchers found that between 2011 and 2013 alone, such investors acquired around 350,000 homes from banks. While some were redeveloped in order to be quickly resold, many were bought with the intention to convert them into rental properties. Thus, the process which began decades earlier found increased potential for growth in the widespread defaulting of mortgages which characterized the period following the 2008 crash. This phenomenon-the working-class losing wealth not through exchange but through expropriation-mirrors what Harvey $(2004,64)$ terms “accumulation by dispossession.” Building on Marx’s $(2001,784)$ earlier notion of "primitive accumulation," Harvey $(2004,73)$ articulates the ways in which contemporary global capitalism continues to rely on dispossession, in addition to exchange and exploitation, in order to maintain acceptable levels of capital accumulation. In this instance, flooding capital into struggling real estate markets amidst a housing crisis staves off potential capital surpluses while allowing global capital to expand into a lucrative sector of the economy with a uniquely low cost of entry due to the state of crisis.

While the 'dispossession' occurring in the form of global capital buying up housing stock lost by working class families who were cheated by subprime mortgages is significant in its own right, this process goes hand in hand with a parallel cite of dispossession in the form of increased gentrification. Elora et al. $(2016,2)$ note that many properties bought up by corporate investors 'redevelop' these properties either to resell immediately or to increase future rents. This investment 
strategy serves as a perfect representation of Smith's rent-gap, with global capital seeking to raise capitalized ground rents as close to potential rents as possible in order to maximize profits for investors. The result, as described by Fields and Uffer $(2016,1495)$, is an increasing rate of gentrification, leading to the displacement of long-term residents and the exclusion of low-income renters. These populations find themselves priced out of areas, allowing investors to continue to buy up and redevelop even more real estate, increasing total rental income and continuing the cumulative process of gentrification. Therefore, and increasingly so, the corporatization of landlordship drives contemporary accumulation by dispossession and therefore exists as a new site of what Harvey $(2004,64)$ identifies as "the new imperialism."

In this new era of imperialism, global capital serves as the mechanism by which economic hegemons can exert influence. Landlord-tenant relations represent an intimate manifestation of this imperialism, whereby working-class individuals anywhere in the world find themselves interacting with agents of global capital in order to secure housing. Linking this new form of imperialism to contemporary landlord-tenant relations allows for connections between this moment and previous incarnations of imperial and colonial extraction. For instance, it has already been discussed how landlordship produces extreme forms of alienation and super-exploitation, e.g. the absentee landlord. The replacement of human landlords with private equity represents an expansion and innovation in this form of extraction. Not only is rent being extracted out of a given community, it is now drawn into the hands of distant finance firms who are not even bound by national borders. Beswick et al. $(2016,322)$ describe how in the four countries who have experienced the most dramatic increases in corporate landlordship - the U.S., Ireland, Spain, and Greece - the institutional investors are typically U.S. based. These four countries in particular, the authors explain, experienced extreme housing crises which prompted the entrance of multinational 
firms into the rental economy. This freedom in the mobility of capital across the globe, with said capital often based in the U.S. and other core countries, illustrates the imperial nature of global capital's entrance into the rental market. It is not difficult to draw the evolutionary connection, then, between methods of super-exploitation pioneered in relations of racialized, colonial extraction, and these new forms of financialized extraction which are expanding to encompass working-class renters globally.

With the introduction of this increased degree of alienation to the general renting population, more and more of those working-class families and individuals face the consequences of renting from a distant and unaccountable landlord. Perhaps the most violent manifestation of this alienation is the increased willingness of corporate landlords to evict tenants. Elora et al. (2016, 17-18) find that even after controlling for neighborhood and property characteristics, private equity landlords were up to $18 \%$ more likely to evict their tenants. Some of the largest corporate landlords served eviction notices to a third of their tenants in a single year. The authors (Elora et al., 2016, 6) explain how eviction creates a traumatic experience for individuals and families both personally and on a community level, noting that a rate of eviction "is associated with poor school outcomes, crime, psychological decline, and fraying of social networks and community ties." The authors explain that in worst case scenarios, evicted tenants face homelessness while at best, these individuals find new_-but comparably worse — housing. Involuntary moves, Elora et al. (2016, 67) continue, "are characterized by greater increases in neighborhood poverty and crime" relative to voluntary relocations. A primary reason why corporate landlords are more willing to seek eviction, Fields and Uffer $(2016,1494)$ find, is due to the pressure to meet projected profit levels. For instance, the authors explain, one analysis of prospectuses filed for several mortgage portfolios (which included approximately 30,000 rental units) revealed profit projections based on "tenant 
turnover rates of $20 \%$ to more than $30 \%$ a year," while average annual turnover rates for many rentals is between $5 \%$ and $10 \%$. Thus, corporate entities basing their actions on purely pecuniary motives have a built-in incentive to achieve and maintain high turnover rates.

A reasonable question to ask in response to the above phenomenon is: why are tenants unable to fight these heightened levels of eviction? The answer relates to the heightened degree of alienation and the geographic and economic distance between tenants and corporate landlords. Fields and Uffer $(2016,1489)$ note that the disconnect between "globalized investors" and tenants reduces opportunities for accountability. Corporate landlords are equipped to outspend tenants in any legal struggle that may ensue, due not only to the lack of wealth on the part of the evicted tenant but also the state of precarity and strain which tenants facing eviction are already experiencing. It is not difficult to imagine how daunting the prospect of entering into a protracted legal battle with an international financial firm would be, especially while struggling to avoid homelessness. This power differential represents the heightened and expanded version of the disparate power relations discussed throughout this paper, with the corporate landlord representing the most developed and powerful incarnation of the landlord seen thus far, existing outside and above most avenues of accountability available to tenants.

\section{Conclusion}

This inquiry has sought to establish that the institution of landlordship has evolved over time, and our exploration into this this trajectory reveals what evolutionary-institutionalist scholars, especially Gunnar Myrdal, have classified and termed as a 'vicious circle.' The subreption of the feudal institution of landlordship by pecuniary values initiated an evolutionary trajectory characterized by an ever-increasing degree of alienation. By stripping away any non-economic 
bonds, tenants have been steadily severed from the shelter which they inhabit, to the extent where the sole relationship between person and housing is that of exchange. The landlord, serving as the seller in this relationship, alienates the tenant from the land while concurrently extracting surplus value from the working class. This extraction follows in the general patterns of capitalist exploitation, including the adoption of colonial methods of super-exploitation. All these developments have found themselves magnified in the most recent phase of the institution's evolution: the financialization of housing and the emergence of the corporate landlord. This development has resulted in an even more intense degree of alienation, and additionally represents the submission of landlordship to corporate hegemony, which has come to characterize contemporary capitalism. These conclusions have been arrived at and revealed through the use of an evolutionary-institutional approach which takes into account the relevant political economy.

There are certain shortcomings of this inquiry which need to be acknowledged. Perhaps the most apparent is the compression of over 400 years of property relations into three moments: the emergence of capitalist landlords in the $15^{\text {th }}$ and $16^{\text {th }}$ centuries, the consolidation of capitalist landlords as seen in the mid-20 $20^{\text {th }}$ century U.S., and the emergence of corporate landlordship over the past few decades. There are other important moments in the history of landlordship which would further inform the evolutionary inquiry undertaken here yet remain beyond its scope. In addition, this study acknowledged, but did not fully explore, the ecological aspects of the alienation of populations from their traditional homes on the land itself. This aspect of capitalistic property relations could indeed warrant a full inquiry. With these shortcomings acknowledged, it is appropriate to reiterate that this effort was meant to serve as an initial foray into the application of the evolutionary-institutional approach to the long history of landlordship. Clearly, further research and discussion is needed. 
At this time, the vicious circle which landlordship has found itself in seems poised to continue. Given that control over housing continues to rest in the hands of those driven by pecuniary values, future changes in the institution of landlordship will likely continue to increase the alienation and instability of the working class. There are, however, possibilities for change.

Yet another strength of evolutionary-institutional economics is its potential for radical critique. This approach reveals that as long as the power to affect further change on an institution rests with those driven by pecuniary values, the spiral will continue. However, should this trajectory be interrupted, and the power to shape future change be left in the hands of those with more humane, socially beneficial principles, the vicious circle could actually be shifted to become a virtuous one. Therefore, shifting ownership and control of the housing stock into the hands of those who actually live there, who benefit not from profit, but from accessibility and sustainability, could potentially reverse the path this institution has taken thus far. Efforts such as accessibilityoriented housing cooperatives, the formation of tenants' unions, and the reclamation of housing stock from corporate investors all represent potential routes forward which could initiate a virtuous circle. At this point, it seems that the institution of landlordship has been so deeply subrepted by pecuniary values that it no longer holds any potential as a socially beneficial institution, if it ever did. Instead, those wishing for improvements in the stability and living conditions of the working class should support the transfer of control over the housing stock to those who inhabit it, for it is they — and not the landlords — who should be leading and shaping the evolutionary process that so profoundly affects their access to shelter. 


\section{Bibliography}

Bailey, Ron. "Economic Aspects of the Black Internal Colony," The Review of Black Political Economy, vol. 3, no. 4 (Summer, 1973): pp. 43-72.

Blauner, Robert. "Internal Colonialism and Ghetto Revolt," Social Problems, vol. 16, no. 4 (Spring, 1969): pp. 393-408.

Breyer, Rob. "The Roots of Modern Capitalism: A Marxist Accounting History of the Origins and Consequences of Capitalist Landlords in England." The Accounting Historians Journal, vol. 31, no. 1 (June 2004): 1-56.

Cilluffo, Anthony et al. "More households are renting than at any point in 50 years." Pew Research Center (July 19, 2017). https://www.pewresearch.org/facttank/2017/07/19/more-u-s-households-are-renting-than-at-any-point-in-50-years/

Connolly, N. D. B. "Timely innovations: planes, trains and the 'whites only' economy of a PanAmerican city." Urban History, vol. 36, no. 2 (2009): 243-261.

Dugger, William M. "Power: An Institutional Framework of Analysis." Journal of Economic Issues, vol. 14, no. 4 (December, 1980): 897-907.

Fields, Desiree and Uffer, Sabina. "The financialization of rental housing: A comparative analysis of New York City and Berlin." Urban Studies, vol. 53, no. 7 (2016): 1486-1502.

Hall, John et al. "Subreption, Radical Institutionalism, and Economic Evolution." Panoeconomicus, vol. 63, no. 4 (2016): 475-492.

Handyside. John (translator). Kant's Inaugural Dissertation and Early Writings on Space. Chicago: The Open Court Publishing Company, 1929.

Harris, Donald J. "Capitalist exploitation and black labor: Some conceptual issues." The Review of Black Political Economy, vol. 8 (December, 1978): 133-151. 
Harris, Donald J. "The Black Ghetto as Colony: A Theoretical Critique and Alternative Formulation.” The Review of Black Political Economy, vol. 2 (September, 1972): 3-33.

Harvey, David. “The 'New' Imperialism: Accumulation by Dispossession.” Socialist Register, vol. 40 (2004): 63-87.

Harvey, David. "Universal Alienation.” Journal for Cultural Research, vol. 22, no. 2 (2018): 137-150.

Lenin, Vladimir I. Imperialism, The Highest Stage of Capitalism. Sydney: Resistance Books [1917] 1999.

Lowery, Ira. "Filtering and Housing Standards: A Conceptual Analysis." Land Economics, vol. 36, no. 4 (November, 1960): 363-370.

Marx, Karl and Engels, Frederick. Capital, Volume 1. New York: Dover, [1867] 2011.

Marx, Karl. Capital Vol. 3. New York: International Publishers, [1894] 1959a.

Marx, Karl. Economic and Philosophic Manuscripts of 1844. Moscow: Progress Publishers, [1844] 1959b.

Marx, Karl. Manifesto of the Communist Party. Pacifica, CA: Marxist Internet Archive, [1848] 2010.

Raymond, Elora et al. "Corporate Landlords, Institutional Investors, and Displacement: Eviction Rates in Single-Family Rentals." Federal Reserve Bank of Atlanta: Community and Economic Development Paper Series, no. 04-16 (December, 2016): 1-21

Ricardo, David. On the Principles of Political Economy and Taxation. Kitchener: Batoche Books, [1817] 2001. 
Smith, Neil. "Toward a Theory of Gentrification: A Back to the City Movement by Capital, not People." Journal of the American Planning Association, vol. 45, no. 4, (1979): 538-548.

Veblen, Thorstein. The Higher Learning in America: A Memorandum on the Conduct of Universities by Business Men. New Brunswick, N.J.: Transaction Publishers, [1918] 1993.

Veblen, Thorstein. The Theory of Business Enterprise. New York: Cosimo Inc., [1904] 2005.

Veblen, Thorstein. "Why is Economics Not an Evolutionary Science?” The Quarterly Journal of Economics, vol. 12, no. 4 (July, 1898): 373-393. 